\title{
ELEVATION OF CYTOSOLIC CALCIUM IN GUARD CELLS
}

\author{
Md. TAHJIB-UL-ARIF ${ }^{1}$, Shintaro MUNEMASA ${ }^{2}$, and Yoshiyuki MURATA ${ }^{3 *}$ \\ ${ }^{1}$ Doctoral Student, Graduate School of Environmental and Life Science, Okayama University \\ (1-1, Tsushima-Naka, 3-chome, Okayama 700-8530, Japan) \\ E-mail: tahjib@bau.edu.bd \\ ${ }^{2}$ Associate Professor, Graduate School of Environmental and Life Science, Okayama University \\ (1-1, Tsushima-Naka, 3-chome, Okayama 700-8530, Japan) \\ E-mail: smunemasa@okayama-u.ac.jp \\ ${ }^{3}$ Professor, Graduate School of Environmental and Life Science, Okayama University \\ (1-1, Tsushima-Naka, 3-chome, Okayama 700-8530, Japan) \\ E-mail: muta@cc.okayama-u.ac.jp
}

\begin{abstract}
Calcium ion $\left(\mathrm{Ca}^{2+}\right)$ is a ubiquitous intracellular second messenger that regulates many cellular processes in plants as well as in animals. Guard cells respond to environmental and internal stimuli, resulting in a change in a stomatal aperture. This signaling pathway employs $\mathrm{Ca}^{2+}$ as a second messenger in the guard cells. Hence, elevation of cytosolic free $\mathrm{Ca}^{2+}$ concentration $\left(\left[\mathrm{Ca}^{2+}\right] \mathrm{cyt}\right)$ can be observed in guard cells treated with phytohormones such as abscisic acid and methyl jasmonate. Several other second messengers including cyclic ADP-ribose, inositol 1,4,5-trisphosphate, and myo-inositol hexakisphosphate are involved in the $\left[\mathrm{Ca}^{2+}\right]$ cyt elevation in the guard cells. Moreover, several methods have been developed to observe the $\left[\mathrm{Ca}^{2+}\right] \mathrm{cyt}$ elevation in the guard cells. In this mini-review, we briefly introduce the roles and regulation of the transient $\left[\mathrm{Ca}^{2+}\right]$ cyt elevation in the guard cells and the methods to monitor the $\left[\mathrm{Ca}^{2+}\right]$ cyt.
\end{abstract}

Key Words: abscisic acid, cytosolic calcium elevation, guard cell, stomatal closure, Yellow Cameleon

\section{INTRODUCTION}

Elevation of the cytosolic calcium concentration $\left(\left[\mathrm{Ca}^{2+}\right]_{\mathrm{cyt}}\right)$ was first observed in guard cells treated with abscisic acid $(\mathrm{ABA})^{1)}$ and subsequently in guard cells treated with external $\mathrm{Ca}^{2+}$, hydrogen peroxide, and cold ${ }^{23)}$. The transient elevation of $\mathrm{Ca}^{2+}$ usually appears at intervals of $10 \mathrm{~min}$ or more and each elevation persists for $1 \mathrm{~min}$ to $4 \mathrm{~min}^{4}$.

The roles of $\left[\mathrm{Ca}^{2+}\right]_{\text {cyt }}$ elevation in ABA signalling are not yet fully understood. Gilroy et al. have demonstrated that the $\left[\mathrm{Ca}^{2+}\right]_{\text {cyt }}$ elevation is essential for stomatal closure ${ }^{5)}$. Siegel et al. have shown slow stomatal closure in Arabidopsis under conditions that prevent $\left[\mathrm{Ca}^{2+}\right]_{\mathrm{cyt}}$ elevation in the guard cells ${ }^{6}$. Romano et al., however, have shown by revealing uninterrupted downstream events that the $\left[\mathrm{Ca}^{2+}\right]_{\mathrm{cyt}}$ elevation is not needed for stomatal closure ${ }^{7}$. Furthermore, Allan et al. have proposed that there may be two ABA signal transduction pathways involved in the $\mathrm{ABA}$-induced stomatal closure; one is $\mathrm{Ca}^{2+}$-dependent and the other is $\mathrm{Ca}^{2+}$-independent ${ }^{8)}$. More recently, Allen et al. hypothesized that certain threshold level of the $\left[\mathrm{Ca}^{2+}\right]_{\text {cyt }}$ elevation regulates the stomatal closure and that a defined pattern of the $\left[\mathrm{Ca}^{2+}\right]_{\mathrm{cyt}}$ elevation is needed to inhibit stomatal reopening or to maintain closure $^{9 \text {. }}$.

In this mini-review, we will briefly describe the roles of the $\left[\mathrm{Ca}^{2+}\right]_{\text {cyt }}$ elevation in ABA-induced stomatal closure and the regulation of the $\left[\mathrm{Ca}^{2+}\right]_{\mathrm{cyt}}$ elevation by second messengers in guard cells. We will also provide a brief description of the measurement of the $\left[\mathrm{Ca}^{2+}\right]_{\text {cyt }}$ elevation in guard cells using a genetically encoded calcium indicator.

\section{ROLES OF $\left[\mathrm{Ca}^{2+}\right]_{\text {cyt }}$ OSCILLATION IN GUARD CELL ABA SIGNALING}

Abscisic acid induces the production of reactive oxygen species (ROS) that can trigger $\mathrm{Ca}^{2+}$ entry into 
the cytosol by stimulating the hyperpolarization-activated $\quad \mathrm{Ca}^{2+}$-permeable channels in the guard cells (Fig.1 $)^{10)}$. Plasma membrane $\mathrm{Ca}^{2+}$-permeable channels are also involved in the generation of external $\mathrm{Ca}^{2+}$-induced $\left[\mathrm{Ca}^{2+}\right]_{\text {cyt }}$ elevation in the Arabidopsis guard cells ${ }^{2}$. The elevation of $\left[\mathrm{Ca}^{2+}\right]_{c y t}$ in guard cells not only depends on the $\mathrm{Ca}^{2+}$ entry across the plasma membrane, but also on the release of $\mathrm{Ca}^{2+}$ from intracellular stores such as the vacuoles, endoplasmic reticulum, and trans-Golgi network. It has been demonstrated that the inositol 1,4,5-triphosphate $\left(\mathrm{InsP}_{3}\right)$-gated $\mathrm{Ca}^{2+}$-release channels in the endomembranes and cyclic ADP-ribose (cADPR)-sensitive $\mathrm{Ca}^{2+}$-permeable channels in vacuoles participate in the $\left[\mathrm{Ca}^{2+}\right]_{\text {cyt }}$ elevation in the guard cells ${ }^{1112)}$. Estimates show that $\mathrm{Ca}^{2+}$ release from intracellular stores accounts for more than 95\% of the $\mathrm{Ca}^{2+}$ entering the cytosol to raise the $\left[\mathrm{Ca}^{2+}\right]_{\mathrm{cyt}}{ }^{4}$.

The elevated $\left[\mathrm{Ca}^{2+}\right]_{\mathrm{cyt}}$ in guard cells inhibits inward-rectifying $\mathrm{K}^{+}$channels to prevent $\mathrm{K}^{+}$uptake and activates both the slow-activating sustained

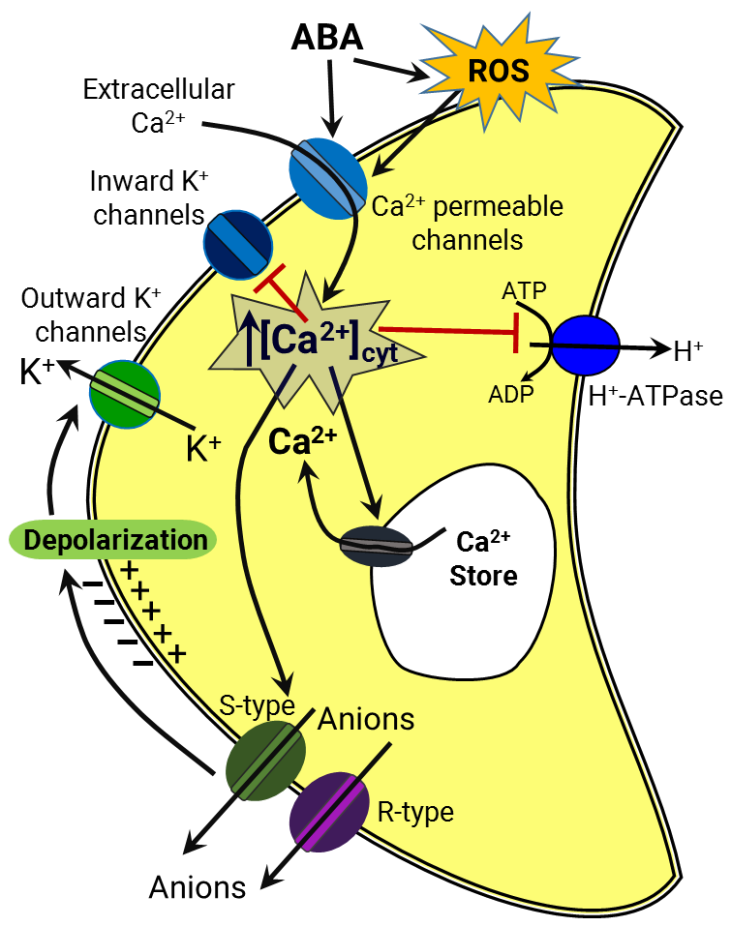

Fig.1 A simplified model showing the roles of the $\left[\mathrm{Ca}^{2+}\right]$ elevation in the guard cells. Elevated $\left[\mathrm{Ca}^{2+}\right]_{\text {cyt }}$ can activate anion channels and can depolarize the plasma membrane. Depolarization activates the outward-rectifying $\mathrm{K}^{+}$channels. Elevated $\left[\mathrm{Ca}^{2+}\right]_{\text {cyt }}$ also inhibits inward-rectifying $\mathrm{K}^{+}$channels and modulates the activity of $\mathrm{H}^{+}$-ATPase in the guard cells.

(S-type) anion channels and rapid transient (R-type) anion channels at the plasma membrane to depolarize the membrane ${ }^{10)}$. These changes are favorable to $\mathrm{K}^{+}$ efflux through the outward-rectifying $\mathrm{K}^{+}$channels, which lead to stomatal closure (Fig.1 $)^{10)}$. In addition to inhibiting the inward-rectifying $\mathrm{K}^{+}$channels and activating anion channels, the $\left[\mathrm{Ca}^{2+}\right]_{\text {cyt }}$ elevation can also modulate the activity of the $\mathrm{H}^{+}$-ATPase (Fig.1). The elevation in $\left[\mathrm{Ca}^{2+}\right]_{\text {cyt }}$ from $0.3 \mu \mathrm{M}$ to $1.0 \mu \mathrm{M}$ inhibits the plasma membrane $\mathrm{H}^{+}$-ATPase in the guard cells of Vicia faba ${ }^{13)}$. This inhibition of $\mathrm{H}^{+}$-ATPase is thought to occur via recruitment of $\mathrm{Ca}^{2+}$ from intracellular $\mathrm{Ca}^{2+}$ stores rather than $\mathrm{Ca}^{2+}$ influx from an apoplastic space ${ }^{13)}$. The $\mathrm{H}^{+}$-ATPase, which can be inhibited by ABA, has been shown to be important in $\mathrm{H}^{+}$pumping required for the membrane hyperpolarization that activates the inward-rectifying $\mathrm{K}^{+}$channels. In addition, the inhibition of $\mathrm{H}^{+}$pumping by ABA-induced $\left[\mathrm{Ca}^{2+}\right]_{\mathrm{cyt}}$ elevation prevents membrane hyperpolarization thereby indirectly contributing to membrane depolarization caused by the $\mathrm{Ca}^{2+}$ influx through the $\mathrm{Ca}^{2+}$-permeable channels ${ }^{14)}$

ABA induces activation of the $\mathrm{Ca}^{2+}$-independent protein kinase Open Stomata 1 (OST1) that activates S-type anion channels, which leads to the release of anions from guard cells and triggers stomatal closure ${ }^{15)}$. The $\left[\mathrm{Ca}^{2+}\right]_{\text {cyt }}$ elevation that occurs before or during stomatal closure augments the activity of the S-type anion channels ${ }^{16}$. As a result of a further stimulation of the S-type anion channels in guard cells, the $\left[\mathrm{Ca}^{2+}\right]_{\text {cyt }}$ elevation seems to accelerate stomatal closure ${ }^{16)}$.

The $\mathrm{Ca}^{2+}$-dependent response is likely to be mediated by the two types of $\mathrm{Ca}^{2+}$-sensor proteins, i.e., $\mathrm{Ca}^{2+}$-dependent protein kinases (CPKs) and calcineurin $\mathrm{B}$-like $(\mathrm{CBL})$-interacting protein kinases (CIPKs) that bind to the CBL proteins ${ }^{16) 17)}$. In the cpk3 cpk6 double and cpk5 cpk6 cpk11 cpk23 quadruple mutants, ABA-induced stomatal closure was impaired ${ }^{18) 19}$, indicating a $\mathrm{Ca}^{2+}$-dependent stomatal signaling pathway. In addition, a recent study found that CIPK23 in combination with either the CBL1 or CBL9 phosphorylates and activates the guard cell S-type anion channels ${ }^{17)}$, suggesting the positive role of the CBL1/9-CIPK23 complexes in the stomatal closure in response to ABA.

\section{THE OTHER SECOND MESSENGERS INVOLVED IN $\left[\mathrm{Ca}^{2+}\right]_{\text {cyt }}$ ELEVATION}

Several second messengers have been identified that regulate the $\left[\mathrm{Ca}^{2+}\right]_{\text {cyt }}$ elevation in the guard cells. In vacuoles, the nanomolar concentrations of cADPR can stimulate the $\mathrm{Ca}^{2+}$ permeable channels ${ }^{12)}$. In guard cells, cADPR initiates transient $\left[\mathrm{Ca}^{2+}\right]_{\mathrm{cyt}}$ elevation and provokes stomatal closure whereas neither an inactive cADPR analog $8-\mathrm{NH}_{2}-\mathrm{cADPR}$ 
nor noncyclic ADPR induces $\left[\mathrm{Ca}^{2+}\right]_{\text {cyt }}$ elevation and stomatal closure ${ }^{20)}$. Moreover, treatment with an inhibitor of cADPR production, nicotinamide, inhibited the ABA-induced $\left[\mathrm{Ca}^{2+}\right]_{\text {cyt }}$ elevation in guard cells as well as partly restrained ABA-induced stomatal closure ${ }^{2021)}$, suggesting that the pathway involving cADPR functions parallel to other $\mathrm{Ca}^{2+}$-dependent pathways in the ABA signal transduction.

The production of $\mathrm{InsP}_{3}$ from phosphatidylinositol 4,5-bisphosphate by hydrolysis mediated by phospholipase $\mathrm{C}$ triggers the $\left[\mathrm{Ca}^{2+}\right]_{\mathrm{cyt}}$ elevation in guard cells, resulting in stomatal closure $^{22)}$. The $\mathrm{InsP}_{3}$ content slightly increases in the ABA-treated guard cell protoplasts and ABA-induced stomatal closure is delayed by a phospholipase $\mathrm{C}$ inhibitor U-73122 ${ }^{11)}$. In addition, production of myo-inositol hexakisphosphate $\left(\mathrm{InsP}_{6}\right)$ induced by ABA inhibits the inward $\mathrm{K}^{+}$channels in a $\mathrm{Ca}^{2+}$-dependent manner in the guard cells ${ }^{23)}$, suggesting that $\mathrm{InsP}_{6}$ is one of the regulators of the $\left[\mathrm{Ca}^{2+}\right]_{\text {cyt }}$ elevation.

\section{OBSERVATION OF $\left[\mathrm{Ca}^{2+}\right]_{\text {cyt }}$ CHANGE IN THE GUARD CELLS}

Generally, there are two available techniques to observe the $\left[\mathrm{Ca}^{2+}\right]_{\text {cyt }}$ change in the guard cells; one is to use calcium-sensitive fluorescence dyes, such as fluo-3 AM and fura-2, and another is to use calcium sensor proteins. For the $\left[\mathrm{Ca}^{2+}\right]$ measurement in living cells, the sensor proteins have several advantages versus the fluorescence dyes because the sensor proteins allow us to monitor $\left[\mathrm{Ca}^{2+}\right]$ in a desired cellular or subcellular location.

One of the sensor proteins, Yellow Cameleon, is composed of a donor chromophore (Cyan Fluorescent Protein, CFP), calmodulin (CaM), a glycylglycine linker, the CaM-binding peptide of myosin light-chain kinase (M13), and an acceptor chromophore (Yellow Fluorescent Protein, YFP) $(\text { Fig.2 })^{24)}$. The binding of $\mathrm{Ca}^{2+}$ to $\mathrm{CaM}$ intensifies the intramolecular interaction between CaM and M13, which brings CFP and YFP close to each other, resulting in an increased efficiency of the Förster Resonance Energy Transfer (FRET) between CFP and $\mathrm{YFP}^{24)}$.

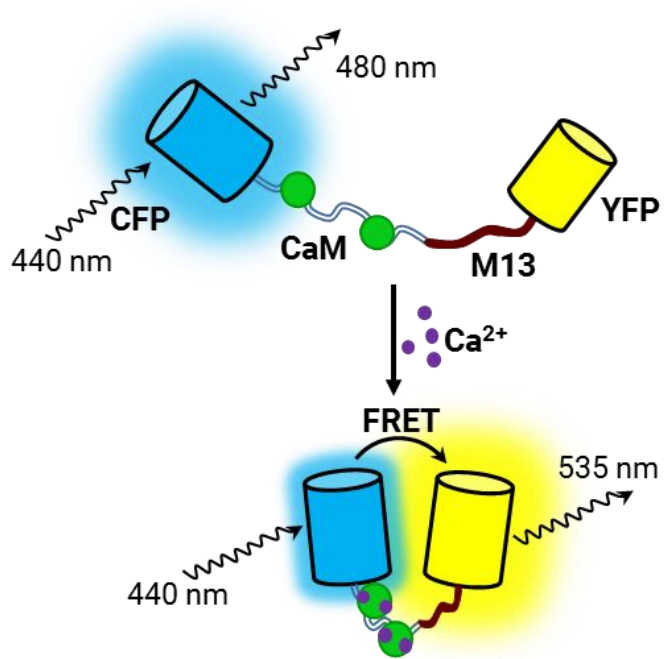

Fig.2 Simplified structure of Yellow Cameleon used to detect cellular $\mathrm{Ca}^{2+}$ changes. Upon an increase in the $\mathrm{Ca}^{2+}$

concentration, calmodulin $(\mathrm{CaM})$ binds $\mathrm{Ca}^{2+}$ and interacts with M13, which induces a conformational change in the protein. This change leads to an increase in the efficiency of FRET from CFP to YFP.

In other words, CFP and YFP stand apart from each other in the Cameleon at a lower $\mathrm{Ca}^{2+}$ concentration, causing a higher intensity of the CFP fluorescence at $480 \mathrm{~nm}$ due to the lower FRET efficiency, whereas CFP and YFP stand close to each other at a higher $\mathrm{Ca}^{2+}$ concentration, leading to a lower intensity of the YFP fluorescence at $535 \mathrm{~nm}$ due to the higher efficiency (Fig.2). Consequently, an increase in $\left[\mathrm{Ca}^{2+}\right]$ elevates the ratio of the YFP fluorescence intensity to the CFP fluorescence intensity. The continuous monitoring of the fluorescence ratio allows the real-time imaging of $\left[\mathrm{Ca}^{2+}\right]$.

\section{REFERENCES}

1) McAinsh, M. R., Brownlee, C. and Hetherington, A. M.: Abscisic acid-induced elevation of guard cell cytosolic $\mathrm{Ca}^{2+}$ precedes stomatal closure, Nature, Vol. 343, pp.186-188, 1990.

2) McAinsh, M. R., Webb, A. A., Taylor, J. E. and Hetherington, A. M.: Stimulus-induced oscillations in guard cell cytosolic free calcium. The Plant Cell, Vol. 7, pp.1207-1219, 1995.

3) Allen, G. J., Chu, S. P., Schumacher, K., Shimazaki, C. T., Vafeados, D., Kemper, A., Hawke, S. D., Tallman, G., Tsien, R. Y., Harper, J. F. and Chory, J.: Alteration of stimulus-specific guard cell calcium oscillations and stomatal closing in Arabidopsis det3 mutant, Science, Vol. 289, pp.2338-2342, 2000.

4) Blatt, M. R., Garcia-Mata, C. and Sokolovski, S.: Membrane transport and $\mathrm{Ca}^{2+}$ oscillations in guard cells, In: Rhythms in plants, Springer, Berlin, Heidelberg, pp. 115-133, 2007.

5) Gilroy, S., Read, N. and Trewavas, A. J.: Elevation of cytoplasmic calcium by caged calcium or caged inositol trisphosphate initiates stomatal closure, Nature, Vol. 346, pp.769-771, 1990.

6) Siegel, R. S., Xue, S., Murata, Y., Yang, Y., Nishimura, N., 
Wang, A. and Schroeder, J. I.: Calcium elevation-dependent and attenuated resting calcium-dependent abscisic acid induction of stomatal closure and abscisic acid-induced enhancement of calcium sensitivities of S-type anion and inward-rectifying $\mathrm{K}^{+}$channels in Arabidopsis guard cells, The Plant Journal, Vol. 59, pp.207-220, 2009.

7) Romano, L. A., Jacob, T., Gilroy, S. and Assmann, S. M.: Increases in cytosolic $\mathrm{Ca}^{2+}$ are not required for abscisic acid-inhibition of inward $\mathrm{K}^{+}$currents in guard cells of Vicia faba L, Planta, Vol. 211, pp.209-217, 2000.

8) Allan, A. C., Fricker, M. D., Ward, J. L., Beale, M. H. and Trewavas, A. J.: Two transduction pathways mediate rapid effects of abscisic acid in commelina guard cells, Plant Cell Vol. 6, pp.1319-1328, 1994.

9) Allen, G. J., Chu, S. P., Harrington, C. L., Schumacher, K., Hoffmann, T., Tang, Y. Y., Grill, E. and Schroeder J. I.: A defined range of guard cell calcium oscillation parameters encodes stomatal movements, Nature, Vol. 411, pp.1053-1057, 2001.

10) Schroeder, J. I., Allen, G. J., Hugouvieux, V., Kwak, J. M. and Waner, D.: Guard cell signal transduction, Annual Review of Plant Biology, Vol. 52, pp.627-658, 2001.

11) Staxén, I., Pical, C., Montgomery, L. T., Gray, J. E., Hetherington, A. M. and McAinsh, M. R.: Abscisic acid induces oscillations in guard-cell cytosolic free calcium that involve phosphoinositide-specific phospholipase C, Proceedings of the National Academy of Sciences, 96, pp.1779-1784, 1999.

12) Allen, G. J. and Sanders, D.: Release of $\mathrm{Ca}^{2+}$ from individual plant vacuoles by both $\mathrm{InsP}_{3}$ and cyclic ADP-ribose, Science, Vol. 268, pp.735-737, 1995.

13) Kinoshita, T., Nishimura, M. and Shimazaki, K.I.: Cytosolic concentration of $\mathrm{Ca}^{2+}$ regulates the plasma membrane $\mathrm{H}^{+}$-ATPase in guard cells of fava bean, The Plant Cell, Vol. 7, pp.1333-1342, 1995.

14) Schroeder, J. I. and Hagiwara, S.: Repetitive increases in cytosolic $\mathrm{Ca}^{2+}$ of guard cells by abscisic acid activation of nonselective $\mathrm{Ca}^{2+}$ permeable channels, Proceedings of the National Academy of Sciences, Vol. 87, pp.9305-9309, 1990.

15) Geiger, D., Scherzer, S., Mumm, P., Stange, A., Marten, I., Bauer, H., Ache, P., Matschi, S., Liese, A., Al-Rasheid, K. A. and Romeis, T.: Activity of guard cell anion channel SLAC1 is controlled by drought-stress signaling kinase-phosphatase pair, Proceedings of the National Academy of Sciences, Vol. 106, pp.21425-21430, 2009.

16) Huang, S., Waadt, R., Nuhkat, M., Kollist, H., Hedrich, R. and Roelfsema, M. R. G.: Calcium signals in guard cells enhance the efficiency by which abscisic acid triggers stomatal closure, New Phytologist, Vol. 224, pp.177-187, 2019.

17) Maierhofer, T., Diekmann, M., Offenborn, J. N., Lind, C., Bauer, H., Hashimoto, K., Al-Rasheid, K. A., Luan, S., Kudla, J., Geiger, D. and Hedrich, R.: Site-and kinase-specific phosphorylation-mediated activation of SLAC1, a guard cell anion channel stimulated by abscisic acid, Science Signaling, Vol. 7, pp.ra86, 2014.

18) Mori, I. C., Murata, Y., Yang, Y., Munemasa, S., Wang, Y. F., Andreoli, S., Tiriac, H., Alonso, J.M., Harper, J. F., Ecker, J. R. and Kwak, J. M.: CDPKs CPK6 and CPK3 function in ABA regulation of guard cell S-type anion-and $\mathrm{Ca}^{2+}$-permeable channels and stomatal closure, PLoS Biology, Vol. 4, pp.e327, 2006.

19) Brandt, B., Munemasa, S., Wang, C., Nguyen, D., Yong, T., Yang, P. G., Poretsky, E., Belknap, T. F., Waadt, R., Alemán, F. and Schroeder, J. I.: Calcium specificity signaling mechanisms in abscisic acid signal transduction in Arabidopsis guard cells, Elife, Vol. 4, pp.e03599, 2015.

20) Leckie, C. P., McAinsh, M. R., Allen, G. J., Sanders, D. and Hetherington, A. M.: Abscisic acid-induced stomatal closure mediated by cyclic ADP-ribose, Proceedings of the National Academy of Sciences, Vol. 95, pp.15837-42, 1998.

21) Klüsener, B., Young, J. J., Murata, Y., Allen, G. J., Mori, I. C., Hugouvieux, V. and Schroeder, J. I.: Convergence of calcium signaling pathways of pathogenic elicitors and abscisic acid in Arabidopsis guard cells, Plant Physiology, Vol. 130, pp.2152-2163, 2002.

22) Tang, R. H., Han, S., Zheng, H., Cook, C. W., Choi, C. S., Woerner, T. E., Jackson, R. B. and Pei, Z. M.: Coupling diurnal cytosolic $\mathrm{Ca}^{2+}$ oscillations to the $\mathrm{CAS}^{-\mathrm{IP}_{3}}$ pathway in Arabidopsis, Science, Vol. 315, pp.1423-1426, 2007.

23) Lemtiri-Chlieh, F., MacRobbie, E. A. C. and Brearley, C. A.: Inositol hexakisphophate is a physiological signal regulating the $\mathrm{K}^{+}$-inward rectifying conductance in guard cells, Proceedings of the National Academy of Sciences, Vol. 97, pp.8687-92, 2000.

24) Miyawaki, A., Llopis, J., Heim, R., McCaffery, J. M., Adams, J. A., Ikura, M. and Tsien, R. Y: Fluorescent indicators for $\mathrm{Ca}^{2+}$ based on green fluorescent proteins and calmodulin, Nature, Vol. 388, pp.882-887, 1997.

(Received: January 29, 2021) 